\title{
The Impact of Government Initiatives in Promoting Racial Equality in Higher Education: A Case Study
}

\author{
Andrew Pilkington \\ University of Northampton
}

\begin{abstract}
This paper will explore the mechanisms by which the British state has encouraged in the last decade universities and other higher education institutions to address issues relating to equality and diversity, generally and race and ethnicity, specifically. Strategies employed by the New Labour government, first elected in 1997, designed to widen (student) participation and promote (staff) equal opportunities will be explicated. It will be argued that these colour blind initiatives had a very limited impact prior to their incorporation into specific duties following the Race Relations (Amendment) Act. The implementation of this legislation initially raised the profile of issues relating to race and ethnicity, but this change proved short-lived and both race and ethnicity, and equality and diversity, issues have subsequently been de-prioritised and fallen down the agenda. While a series of commissioned evaluations suggest that government initiatives have made a significant difference and that universities have made progress in promoting race equality and acknowledging ethnic diversity, deconstruction of the discourses underpinning these official evaluations reveals significant lacunae and remarkable continuities.
\end{abstract}

This year witnesses the tenth anniversary of the publication of a judicial inquiry chaired by Lord Macpherson into the racist murder of a young Black British man. The publication of the inquiry report (Macpherson 1999) was in many ways remarkable because of its admission that major British institutions were characterised by 'institutional racism' and the widespread acceptance by the State that action needed to be taken. Taking the case of Britain, I shall investigate in this paper pressures emanating on the academy from the State: government strategies for higher education, relating to both widening participation and human resources, and new race relations legislation. I shall focus predominantly, but not exclusively, on the period 1999-2003 when pressure was arguably at its most intense, and concentrate on the impact of these external forces on the sector's approach to and policies relating to race. The impact of each of these external forces identified above will be examined in turn for ease of exposition. It should be noted, however, that this is somewhat artificial since they overlap in practice with the result that it is difficult to disentangle the impact of each.

\section{Universities and the State}

In Britain, universities are formally independent and autonomous institutions. Nonetheless, there is little doubt that in the last two decades the state has exerted an increasing influence on higher education and that 'considerable centralisation has taken place' (Davies et al 1997, p. 7). The capacity of the state to influence higher education stems, above all, from the sector's dependence on state funding and the insistence that universities, along with other public bodies, are accountable for the way they spend public money (Davies et al 1997). The approach of the New Labour government to higher education has been underpinned by 'two guiding principles...building economic prosperity and promoting social justice' (Hodgson \& Spours 1999, p. 98). In practice these two principles have sometimes been in tension, with the measures being taken to support universities that can compete in the global market place being at odds with those required to provide 'fair access to worthwhile higher education' (Jary \& Jones 2006, p. 14). Nonetheless, it is abundantly clear that the government has increasingly been concerned to ensure that higher education is instrumental in serving certain economic and social imperatives.

The government allocates funding for higher education in England through the Higher Education 
Funding Council of England (HEFCE). Each autumn, the government confirms the total grant for the sector for the following year and in the subsequent funding letter sent to HEFCE identifies its spending priorities. HEFCE then allocates the funding due to individual Higher Education Institutions (HEIs) in February. This takes the form of a block grant covering research and teaching funding allocated in terms of specific formulae. In addition to this, HEFCE also allocates special funding for new initiatives which are reviewed each year and subsequently may be phased out or incorporated into formula funding. These special funding initiatives have included some that are of immediate interest here because they relate to government priorities to widen participation and promote equal opportunities.

The government's concern that universities widen participation for students and promote equal opportunities for staff was made amply clear by the Secretary of State for Education and Employment in his funding letter to HEFCE in November 1999 (HEFCE 2008a). The previous year's funding letter in December 1998, for the first time, signalled the government's 'commitment to widening access' (HEFCE, 2008a, para. 18). The 1999 funding letter went further: 'Widening access to higher education is a key priority and critical to tackling social exclusion' (HEFCE 2008a, para. 19). On equal opportunities, the 1999 funding letter expressed itself in no uncertain terms:

I am deeply concerned about the present position on equal opportunities for HE staff. Evidence suggests that only a minority of academic staff in higher education institutions are from an ethnic minority background, are women, or have a disability, and that relatively few from these groups reach senior positions (HEFCE 2008a, para. 27).

The government's concern to widen participation and promote equal opportunities is only partially concerned with race and ethnicity. This is evident from a comparison of successive funding letters (HEFCE 2008a). Blunkett's 1999 funding letter made no reference to race and ethnicity in the section on 'widening access' (HEFCE 2008a, para. 19-24) and subsequent funding letters, which have continued consistently to prioritise widening participation, have followed suit. When it comes to staff as opposed to students, Blunkett's 1999 funding letter was unprecedented in emphasising race equality in the section on 'equal opportunities for HE staff': 'I am particularly concerned to see institutions make progress on race equality for staff' (HEFCE 2008a, para. 27). Subsequent funding letters, in contrast, when they have emphasised the importance of equal opportunities, have not expressly mentioned race and ethnicity. The emphasis placed on race equality in 1999 reflected the high profile given to the Macpherson report earlier in that year. The absence of any reference to race and ethnicity thereafter indicates that the strategies to widen participation and promote equal opportunities were colour blind strategies focused on social disadvantage.

\section{New Labour and Widening Participation}

Since 1998, widening participation has been a key concern of government policy. The government's approach, however, has been criticised because many of the measures taken are based on a notion of the individual student as deficient rather than based on an acknowledgement of system failure. Here are two examples: 'New Labour policies appear to be based on a "deficit" model where initiatives are designed to address the perceived inadequacies of excluded groups' (Hayton \& Paczuska 2002, p. 259).

While the momentum to enhance participation in higher education is laudable...[it] is based on a simplistic access model in which the wire is lifted to allow a small minority of members of underrepresented groups to enter the academy. The onus of change is on those groups, rather than the academy as an organisation (Morley 2003, p. 11-12).

In support of such critiques, research evidence on widening participation across the student lifecycle has pointed to little evidence of teaching approaches and assessment methods being adapted for diverse learners but rather an emphasis on students needing to learn to adapt to HE (Thomas, May et 
al 2005). A recent review of widening participation research reaches a similar conclusion in pointing out 'how little effect the WP agenda has had in "changing the product" within HE itself' (Watson, 2006, p. 5).

There is little doubt that widening participation is primarily concerned with class. Despite the occasional references made by government Ministers to 'BME learners' (NATFHE 2000), their needs are of only marginal concern to key policy makers. The central focus of attention is social class. This is evident in a number of ways. The funding letters never mention race or ethnicity but invariably refer to social class or a proxy measure of it (HEFCE, 2008b). A search of articles that I conducted in the Times Higher Educational Supplement for the period 1994-2004 reveals 510 references to widening participation. While only 20 of these references refer to race or ethnicity (and gender for that matter), as many as 201 of these references explicitly refer to class. It is also significant that the three books Universities UK have commissioned on widening participation explicitly focus on class. They address how universities are supporting access to HE for young people from lower socio-economic groups and identify examples of good practice (Woodrow 1998; Woodrow, Yorke et al 2002; Thomas, May et al 2005). While it is true that a few of these cases are targeted at specific minority ethnic groups, the overwhelming emphasis is on class. A final indication that widening participation is in practice primarily concerned with class, relates to the performance indicators used. These are wholly class based.

The Dearing inquiry (1997) commissioned research into widening participation by various groups, with report 5 covering 'ethnic minorities'. This report did identify a number of pertinent issues that related to students from minority ethnic groups. Specific groups, including Afro-Caribbean men and Bangladeshi women, were under-represented in the sector; and students from BME communities were concentrated in the less prestigious post 1992 universities, experienced a sense of isolation and gained a lower rate of return on their HE qualifications than White students. Despite this, the good news identified in the first paragraph was given more prominence: 'Relative to their share in the population...ethnic minorities overall are now better represented in HE than whites' (Coffield \& Vignoles 1997, para. 1.1). This emphasis is common in many policy documents. Here are two examples. Firstly: 'Many ethnic groups continue to be over-represented in higher education compared to their population share' (Universities UK (2005) quoted in Aimhigher 2006, p. 2). Secondly: 'Those from non-white ethnic groups are better represented than white people' (National Audit Office 2008, para. 5). The problem with such an emphasis is that it 'selectively uses particular pieces of research to make the case that the under-representation of...ethnic minorities has been largely solved' (Webb 1997, $p$. 85). As a recent review of $\mathrm{BME}$ participation in $\mathrm{HE}$ argues, little specific action is being taken in relation to BME needs 'because major bodies are working from headline statistics that are undifferentiated'. The result is that 'the needs of BME learners are mostly rolled up into generic widening participation policies' which effectively means that 'BME participation is dropping off the agenda' (Aimhigher 2006, p. 2).

Despite the fact that the binary divide between universities and polytechnics was abolished in 1992, the higher education sector remains highly stratified (Davies et al 1997). This means that as we 'move to a mass system of higher education... it is increasingly important that we consider the different sorts of higher educations that are now on offer' (Reay et al 2005, p. vii). When we do this, we discover that students from minority ethnic backgrounds are 'far more likely to be negatively positioned within the higher education system and to study less prestigious subjects in less prestigious institutions' (Jary \& Jones 2006, p. 7). A recent study which examined students' choices of higher education revealed that 'while more working class and ethnic minority students are entering university, they are generally entering different universities to their white middle class counterparts. Class tendencies are compounded by race' (Reay et al, 2005, p. 162). The focus on admissions to the sector as a whole glosses over the differentiated nature of the higher education sector and overlooks the different rates 
of return from going to different institutions.

A recent analysis of what institutions do under the heading of widening participation is revealing. HEls receive funding for widening access and improving retention but, despite the fact that they receive more for improving retention, most activities focus on access rather than success. Using the student life cycle to identify different stages, Thomas and May (2005) discovered that $64 \%$ of activities were related to pre-entry, for example aspiration raising, and that only $13 \%$ of activities were concerned with supporting student success and employability. As the authors put it, 'This study suggests that the sector is prioritising pre-entry and access initiatives at the expense of interventions once students have entered HE' (Thomas, May et al 2005, p. 193). This finding is significant and has adverse consequences for minority ethnic groups who are more likely to gain access to the sector but disproportionately face problems in succeeding.

\section{New Labour and Equal Opportunities}

The priority given by New Labour to widening participation for students has been accompanied by a concern with equal opportunities for staff. Although the latter has been a much longer standing issue for the sector than the former, Blunkett's funding letter in November, 1999 to the sector, highlighted the need for the sector to take decisive action to promote equal opportunities. HEFCE took the lead, with its two most important initiatives being (co)funding the Equality Challenge Unit (ECU), a new sector wide advisory body, and requiring university human resources strategies to address equal opportunities.

Blunkett's funding letter in November 1999 emphasised the importance of race equality and his words were still fresh at the launch of the ECU in February 2001. Reference was made to the Macpherson report and there was a recognition that the ECU needed to address race as well as gender and disability. As the Macpherson report receded, however, less emphasis was placed on race. The funding letters from 2000 onwards, for example, do not make any explicit reference to race or ethnicity when they mention equal opportunities.

We shall focus here on the two major HEFCE funded initiatives in turn. Firstly, the Equality Challenge Unit (ECU) and secondly, the equal opportunities component of human resources (HR) strategies.

\section{The Equality Challenge Unit}

The ECU was launched in February, 2001 and became formally operational in August, 2001. Although the dominant discourse at the launch talked about building on earlier achievements, the creation of ECU entailed an acknowledgement that earlier initiatives in promoting equal opportunities had not been sufficiently effective. The unit initially focused on race, given the requirements of the legislation, but over time, inevitably, attention has shifted from race to other strands of equality as new legislative measures relating to other strands of equality have been introduced.

An independent evaluation of the unit, based on semi-structured interviews with a range of groups, was conducted in 2005 (HEFCE 2005a). It acknowledged that the unit not only had played an effective advisory and awareness role, but also had produced high quality guidance publications. It was critical, however, of the extent to which the ECU had supported individual HEls in implementing change. In many ways what is most revealing about this evaluation of the ECU is what it reveals about the sector. We are informed that 'there is no opposition to good EO [Equal Opportunity] practice' only for this to be followed in the same sentence by the observation that 'some institutions are more attuned to equal opportunities issues than others' (HEFCE 2005a, p. 3). This hint that 'an awareness of the importance of EO' is not universally shared across the sector is made more explicit later in the report. While it is argued that 'there is an awareness of the importance of EO among senior managers and human resource and EO practitioners...middle managers, heads of school or departments to whom 
key human resource functions are often devolved, sometimes have a (perhaps complacent) view, despite some evidence to the contrary, that EO issues have no place in a meritocracy' (HEFCE 2005a:, p. 26).

\section{Human Resources Strategies}

Following the government's spending review in 2000, HEFCE provided additional funding to reward and develop staff (R\&DS) from 2001-02 to 2003-04. This special funding was designed to modernise HR systems and the processes of recruiting, retaining, rewarding and developing staff. The funding was allocated to each $\mathrm{HEl}$ in proportion to its block grant on receipt of a 3 year HR strategy. HEls were invited to submit either full or emerging human resources strategies to HEFCE by June 2001. Most HEls submitted emerging strategies which allowed them another year to develop full strategies. These strategies were expected to cover 6 priority areas. One of these pertained to equal opportunities: 'Develop equal opportunities targets, with programmes to implement good practice throughout an institution. This should include ensuring equal pay for work of equal value, using institution-wide systems of job evaluation' (HEFCE 2005b, p. 19).

An evaluation of this initiative was conducted in May 2005. Based primarily on questionnaires to HR Directors, its conclusion was positive. The 'initiative was worthwhile because it provided a focus for change and has had a positive impact across the English HE sector' (HEFCE, 2005b: 4). When we turn to equal opportunities, the evaluation discovered that 'the largest proportion of funding within this priority area had been allocated by institutions to address job evaluation'. In the light of this, it is perhaps not surprising that 'activities undertaken...appear to have had the greatest impact on the role and reward of women in the majority of institutions' and that as a result 'the role of minority ethnic groups...has received much less emphasis...compared to the emphasis on gender equality' (HEFCE 2005b, p. 10). Further evidence that race issues had been sidelined relative to gender issues was submitted by 'some union stakeholders' who 'believed that the race aspects of job evaluation have not been considered' (HEFCE 2005b, p. 56).

Previous research has indicated that equal opportunities policies in higher education tend to focus on gender rather than race (Neal 1998; Law et al 2004). The evidence above that the implementation of HR strategies entailed a greater concern with gender than race issues suggests that this prioritisation persists. Further, albeit limited, supporting evidence along the same lines emerges from a search that I conducted in the Times Higher Educational Supplement for the period 1994-2004. This reveals 504 references to equal opportunities. While 97 of these references refer to race or ethnicity (and 56 to class), 186 references refer to gender or women.

The evaluations of both the ECU and the R\&DS initiative are, for all their limitations, quite interesting. It is worth deconstructing these discourses. For, while they tend to highlight positive developments and downplay negative ones, a careful examination of them reveals serious lacunae in the way many HEls are pursuing equal opportunities and thereby race equality. The evaluation of the ECU claims that 'the sector is asking for support in implementing change in equal opportunities practice' but it is doubtful that the sector holds one position. For the evaluation reveals (see above) that many key staff do not believe in the importance of EO, and other research indicates that many staff are in fact highly sceptical of the efficacy of equal opportunities policies (Deem et al 2005). The purported consensus suggested above, in conceiving the sector as a subject, turns out to be spurious. On closer examination, 'the sector' refers to senior managers who are conceived as keen to promote equal opportunities but in need of support. The ECU and HEFCE have both in fact produced excellent guidance, but the analysis of HR strategies identifies significant deficiencies in monitoring (HEFCE 2002/14, para. 143 in HEFCE, 2007) and in target setting HEFCE 2003/37, para. 27 in HEFCE 2007). There is a plethora of excellent guidance documents and yet the implementation of equal opportunities policies is, to put it mildly, uneven. 
This research is consonant with other research, showing that equal opportunity policies do not pursue 'the needs of all groups with equal vigour' (Iganski \& Mason 2002, p. 151). Insofar as data has been collected on the impact of mainstream programmes on minority ethnic groups, the evidence indicates that these 'have not been as successful for ethnic minorities when compared with Whites' (PIU 2002 quoted in Pilkington 2003, p. 241). It has been widely recognised for a long time that an organisation intent on preventing or detecting racial discrimination needs to undertake both 'ethnic monitoring and the setting of targets' (Sanders 1998, p. 38). Seen in this light, the evidence above, which points to failures in data gathering and target setting, suggests that many HEls have not taken equal opportunities policies seriously.

\section{Race Relations Legislation}

Let us turn finally to an approach that is explicitly concerned with race. The government's major response to the Macpherson report was a legislative initiative, the Race Relations (Amendment) Act (RRAA), 2000. The Act extended the scope of the 1976 Act by covering public bodies which had been previously exempt and making it unlawful for public authorities to discriminate in carrying out any of their functions. While this Act, like previous race relations legislation, prohibited unlawful discrimination, a new approach was also evident. For the first time, a general statutory duty was placed on all public authorities, and specific duties on some authorities, to eliminate racial discrimination (including indirect discrimination), promote good race relations and facilitate equality of opportunity. The Act gave the Commission for Racial Equality (CRE) the power to develop a statutory code of practice and provide guidance to public authorities on how to meet the general duty and any specific duties introduced by the Home Secretary. By enjoining public bodies in this way to develop policies and plans which promote racial equality, the Act adopted a very different approach to that embodied in previous race relations legislation: public authorities were now being required to take a pro-active stance to racial equality and thus take the lead in eliminating racial discrimination, promoting good race relations and facilitating equal opportunities.

The deadline in England and Wales for the production of race equality policies with plans of implementation was set for May 2002. The specific duties for HEls were:

Prepare and maintain a written race equality policy and implementation plan;

- Within the policy and plan assess the impact of institutional policies on staff and students from different racial groups;

- Within the policy and plan monitor the applications, admissions and progression of students;

- Within the policy and plan monitor the recruitment and development of staff ;

- Within the policy and plan set out arrangements for publishing the race equality policy and the results of monitoring impact assessments and reviews.

What is interesting about these specific duties is what they prioritise. They do not, unlike the AntiRacist Toolkit produced by Leeds University (Turney et al 2002), focus on teaching and research, but on widening participation and equal opportunities (Sharma 2004). The colour blind widening participation and equal opportunity policies may, as we have seen, have bypassed minorities, but targeted policies it was hoped would make a difference

In order to fulfil its statutory obligations under the RRAA, HEFCE required HEls to submit their race equality policies and plans for review in November 2002. The Equality Challenge Unit was asked to review them on behalf of HEFCE, with the review itself being undertaken by the Gus John Partnership in terms of a template devised by the Equality Challenge Unit.

The outcome of the review entailed placing each policy and plan into one of five categories:

- An exemplar of good practice at this stage in the implementation process (E);

- Good/Good with certain areas needing attention (G); 
- Developing appropriately but with significant areas needing attention (D1);

- Developing appropriately but with major work to be done (D2);

- Not yet aligned with the requirements of the RRAA; needing urgent revision ( $N$ ).

While $34 \mathrm{HEls}$ were categorised as having developed 'exemplary' policies, $45 \mathrm{HEls}$ (deemed to be $\mathrm{N}$ and D2) were categorised as having submitted policies and plans which did not meet the requirements of the RRAA and required further work (John 2005). HEls judged to be $\mathrm{D} 2$ or $\mathrm{N}$ were required to resubmit their policies and plans within three months.

The Office of Public Management (OPM) was commissioned to do a subsequent review in 2003. The policies and plans of $45 \mathrm{HEls}$ who had initially been judged to be $\mathrm{D}_{2}$ or $\mathrm{N}$ were reassessed using the same template and grading system as the initial review. The report in July concluded that, although the majority of HEls had made significant progress, 17 were judged to have policies and plans that were categorised as $\mathrm{N}$ or $\mathrm{D} 1$ and thus were still not compliant with the legislation. These $17 \mathrm{HEls}$ were again reassessed in 2004 by OPM by which time only 4 were judged noncompliant (OPM 2004a).

In addition to these compliance reviews of higher education institutions commissioned by the ECU on behalf of HEFCE, the CRE commissioned Schneider-Ross to provide a review of the response of public sector organisations to the requirement to have developed race equality policies and plans. The fieldwork began in November 2002, six months after the date for meeting the specific duties. The research comprised two elements: a questionnaire and an analysis of a random sample of race equality polices and plans (Schneider-Ross 2003). Despite evident progress, implementation of the duty in all sectors was patchy. In the case of $\mathrm{HE}, 98 \mathrm{HEls}$ responded to the questionnaire and 12 policies were analysed. $95 \%$ reported having a scheme in place but only about a third indicated that monitoring was underway and the proportion indicating that they had in place a timetabled set of race equality outcomes was no better. To put this in some comparative perspective, HEls scored markedly less well than the police in terms of monitoring and target setting. Analysis of HEl policies and plans revealed a mixed bag: 2 needed development; 4 were partially developed; 4 were mainly developed; and 2 were fully developed.

Finally, OPM was commissioned to review, two years after the original deadline for submission of race equality policies and plans, how HEls were implementing their policies and plans. The review was upbeat:

This review of progress, two years after initial race equality policies and action plans were developed, shows the considerable progress travelled by the majority of HEls...80 per cent are making fair progress, and of these some are showing real innovation and good practice in different areas (OPM 2004b, p. 23).

Given that a report published a mere 5 years earlier indicated that only a few HEls had a race equality policy at all, such an upbeat position is understandable. However, it should be noted that this review, like the compliance reviews, was desk based and that the reality on the ground may be different. As the third compliance review acknowledges,

It is important to reiterate that the existence of a strong policy document does not necessarily mean that progress is being made on the ground. Indeed, in some instances...policy documents have been produced by external consultants, and it is not clear to what extent commitments are owned by the university (OPM 2004a, p. 12).

\section{Deconstructing the evaluative discourses}

It is instructive to compare the OPM overview report with the initial review of race equality policies 
and plans conducted by the Gus John Partnership. There are markedly different discourses at work and these point in turn to markedly different perspectives on the progress HEls have made.

John, who writes from an antiracist approach, is clearly appalled by the lack of progress made:

Having regard to the fact that the ECU provided ample guidance and support to HEls to assist them in drawing up their policy and implementation plan, and that the CRE issued guidance and fielded numerous telephone and written enquiries, the...results suggest that many HEls were still struggling to come to terms with what the legislation requires and that they remain on a steep learning curve. What is more, it begs the question as to what precisely HEls had done previously in response to Section 71 of the 1976 Race Relations Act, and as a result of the findings and recommendations of the Stephen Lawrence Inquiry Report. In addition to work by the ECU and the CRE, HEFCE itself has promoted initiatives on, for example, widening participation and improving access for people with disabilities. One would have expected, therefore, an approach to meeting the requirements of the RRAA 2000 which at least demonstrated an understanding of the structural bases of social exclusion, and the extent to which institutions could be implicated in the perpetuation of it unless proactive steps were taken to identify and eliminate the conditions that sustain it (John 2003, p. 2).

The ECU, as an advisory body funded by the sector, cannot afford to be as critical of HEls. Since it would be fatal for it to be at odds with the sector, the approach adopted is to go with the grain and coax HEls much more gently. The template devised by the ECU to classify institutional policies and implementation plans thus errs on the side of generosity. Of the five categories, only one is manifestly scathing: 'Not yet aligned with RRAA requirements'. The others are labelled 'exemplars'; 'good'; and (in the case of two) 'developing appropriately'.

Gus John uses this template but his discourse is often at odds with the more positive gloss intended by ECU:

Just under half of the HEls failed to heed the guidance...For some $60 \%$ of those, their policies and plans were so wide of the mark as to suggest a total lack of interest in the issue...Across the sector, and even in the case of exemplars, there were few examples of institutions systematically consulting with black and minority ethnic staff and students... Most troubling is the evidence of an insistence upon reducing the emphasis that the Act places on...race equality, and subsuming the intentions of the legislation under broader and more amorphous and ill-defined concepts such as equal opportunities... Regrettably, much of what is contained in the policies we examined is a reflection of the marginal status afforded black and minority ethnic staff and students in the sector...lt would appear that many institutions believe that it does not really matter whether or not they demonstrate evidence of meeting the requirements of the RRAA 2000 (John 2003, p. 3-9).

Given his scepticism about the likelihood of the sector seriously addressing race equality without significant pressure, John recommends the establishment of a 'Black Staff Commission' to generate internal pressure and performance related funding to generate external pressure from HEFCE on HEls: 'Given the inertia that accompanied the Race Relations Act 1976 and the performance of the sector on "race" issues prior to the RRAA 2000, there is good reason to give HEls a wake-up call by linking their funding to their performance in respect of the duty under the RRAA 2000' (John 2003, p. 10). John's proposals were not taken up and the subsequent compliance reviews as well as the progress overview were undertaken by a different consultancy company, the Office for Public Management (OPM).

The OPM took their cue from the ECU and adopted a discourse that highlighted positive developments. Hence, as we saw above, the upbeat nature of the progress overview, which pointed to 'the considerable distance travelled by the majority of HEIs' (OPM 2004b, p. 23). The key players at HEFCE, ECU and the HEls could thus be assured that the sector was on the right tracks and that there was therefore no need for the radical changes suggested by John. Jettisoning any radical proposals, OPM 
chose instead to put forward a set of discrete recommendations. While these recommendations may initially suggest that only minor tweaks are needed, a deconstruction of the discourse reveals some serious 'weaknesses...across institutions' (OPM 2004b, p. 23). The recommendations signal the need for improvements in a wide range of areas: 'celebrating the importance of race equality...consultation and engagement...training... monitoring... recruitment ...action plans ...mainstreaming...targets... accountability...sharing good practice...reporting...resources' (OPM 2004b, pp. 23-26). What is more, the weaknesses revealed in many of these areas are fundamental. While OPM may employ a different discourse from John and highlight progress, it is evident from reading between the lines that the sector has a long way to go.

It must be remembered that the secondary research I have drawn upon above to evaluate the impact of government strategies and legislation is limited. It is often based on questionnaires to senior staff or based on analysis of written documents. Both methods have their biases. The first method invariably tends to present institutions in a favourable light; since senior staff are loath to be publicly self critical and are concerned, in a Goffmanesque way, to manage the impression of their organisations. The second method also tends to present institutions in as favourable a light as possible. There is an acute awareness that public documents present images of the organisational ethos. Those responsible for their production therefore are often concerned to massage these images so that they are positive. There is also another danger with documents - that we confuse what is written in strategic and policy documents with what actually happens in institutions. Since strategic and policy documents often serve as the public face of the university, an inordinate amount of time can go into getting them just right. This can mean that writing documents and having good policies becomes a substitute for action: as one of Ahmed's interviewees put it, "you end up doing the document rather than doing the doing"' (Ahmed 2007, p. 599). We clearly need to move beyond such methodologies to assess what actually happens on the ground. That, however, is the subject of another paper.

\section{Summary}

The publication of the Macpherson report in 1999 significantly raised the profile of race equality and prompted a series of government initiatives to promote race equality. The focus of this paper has been on higher education. Analysis of the impact of different government initiatives has revealed that the changes afoot are much less remarkable than the continuities. The colour blind initiatives had little impact at all in promoting race equality. The more targeted initiatives stemming from the Race Relations (Amendment) Act initially had an impact. Their impact, however, was short lived, with a deconstruction of the discourses in the official evaluations pointing to significant lacunae. What is more, the pressure is now off. Although lip service continues to be paid in government pronouncements and some strategies to race equality and ethnic diversity, a discourse centred on community cohesion has become hegemonic and has marginalised one concerned with race equality and ethnic diversity (Pilkington 2008). In the light of this, it is scarcely surprising to discover that BME academic staff continue to experience significant disadvantage in higher education ten years after the publication of the Macpherson report (Leathwood et al 2009).

\section{References}

Ahmed, S (2007) "You end up doing the document rather than doing the doing": Diversity, Race Equality and the Politics of Documentation. Ethnic and Racial Studies, 30(2).

Aimhigher (2006)). A Review of Black and Minority Ethnic Participation in Higher Education, [Online]. (last accessed 20/08/08) (URL www.aimhigher.ac.uk/sites/practitioner/resources/Conf\%20 Summary\%2oreport\%)

Davies, P., Williams, J. \& Webb, S. (1997). Access to Higher Education in the Late Twentieth Century: 
Policy, Power and Discourse in: Williams, J. ed Negotiating Access to Higher Education, Buckingham: SRHE/Open University Press.

Dearing, R. (1997). The National Committee of Inquiry into Higher Education. [Online]. (last accessed 27/05/05) (URL www.leeds.ac.uk/educol/ncihe/)

Deem, R., Morley, L. \& Tlili, A. (2005).

Negotiating Equity in Higher Education Institutions. [Online]. (last accessed 30/05/08) (URL www. hefce.ac.uk/pubs/redreports/2005/rd10_05/rd10_05doc)

Hayton, A. \& Paczuska (2002). Conclusion: Is Higher Education Gladdening Our Existence? in Hayton, A. and Paczuska, A. eds. Access, Participation and Higher Education, London: Kogan Paul.

HEFCE (2005a). Evaluation of the Equality Challenge Unit: Report to HEFCE by SOW Limited,[Online]. (last accessed 20/08/08). (URL www.hefce.ac.uk/pubs/rdreports/2005/rd27_05/)

HEFCE (2005b). Evaluation of Rewarding and Developing staff in HE Initiative 2001-02 to 2003-04, [Online]. (last accessed 27/05/05).(URL www.hefce.ac.uk/pubs/rdreports/2005/rd14_05/)

HEFCE (2007). Rewarding and Developing Staff in Higher Education, [Online]. (last accessed 21/08/08). (URL www.hefce.ac.uk/lgm/hr/reward/ )

HEFCE (2008a). Grant Letter from the Secretary of State to HEFCE, [Online]. (last accessed 20/08/08). (URL www.hefce.ac.uk/finance/fundinghe/grant/)

HEFCE (2008b). Widening Participation, [Online]. (last accessed 20/08/08). (URL www.hefce.ac.uk/ widen/ )

Hodgson, A. \& Spours, K. (1999). New Labour's Educational Agenda. London: Kogan Paul.

Iganski, P. \& Mason, D. (2002). Ethnicity, Equality and the British National Health Service. Aldershot: Ashgate.

Jary, D. \& Jones, R. (2006). Overview of Widening Participation Policy and Practice in: Jary, D. and Jones, R., eds. Perspectives and Practice in Widening participation in the Social sciences, Birmingham: C-SAP.

John, G. (2003). Review of Race Equality Policies and Action Plans in HEFCE-funded Higher Education Institutions. [Online]. (last accessed 20/08/08). (URL www.hefce.ac.uk/lgm/divers/ecu)

John, G. (2005). Taking a Stand, Manchester: Gus John Partnership.

Law, I., Phillips, D. \& Turney, L., eds. (2004). Institutional Racism in Higher Education. Stoke on Trent: Trentham Books.

Leathwood, C., Maylor, U \& Moreau, M. (2009). The Experience of Black and Minority Ethnic Staff Working in Higher Education, London: Equality Challenge Unit.

MacPherson, W. (1999). The Stephen Lawrence Inquiry: Report of an Inquiry by SirWilliam Macpherson of Cluny. London: HMSO. 
Morley, L. (2003). Quality and Power in Higher Education, Maidenhead: SRHE/Open University Press.

NATFHE (2000). Learning Through Diversity. London: NATFHE.

National Audit Office (2008). VFM Report: Widening Participation in Higher Education. [Online]. (last accessed 20/08/08). (URL www.nao.org.uk/publications/nao_reports/07-08/0708725es.htm )

Neal, S. (1998). The Making of Equal Opportunity Policies in Universities. Buckingham: SRHE/Open University Press

OPM [Office of Public Management] (2004a). Assessment of Race Equality Policies and Plans in HEFCE-funded HEls. [Online]. (last accessed on 01/08/08 (URL www.hefce.ac.uk/Pubs/rdreports/2004/ rdog_04/)

OPM [Office of Public Management] (2004b). Review of Progress in Race Equality. [Online]. (last accessed on 01/08/08) (URL www.hefce.ac.uk/Pubs/rdreports/2004/rdo9_04/)

Pilkington, A. (2003). Racial Disadvantage and Ethnic Diversity in Britain, Basingstoke: Palgrave.

Pilkington, A. (2008). From Institutional Racism to Community Cohesion: The Changing Nature of Racial Discourse. Sociological Research Online, 13(3).

Reay, D., David, M. \& Ball, S. (2005). Degrees of Choice. Stoke on Trent: Trentham Books.

Sanders, P. (1998). Tackling Racial Discrimination in Blackstone, T, Parekh, B. and Sanders, P., eds. Race Relations in Britain. London: Routledge.

Schneider Ross. (2003). Towards Racial Equality. London: CRE.

Scott, P. (2005). Mass Higher Education - Ten Years On. [Online]. (last accessed 20/08/08) (URL www. aua.ac.uk/publications/conferenceproceedings/2005warwick/peterscott.doc- )

Sharma, S. (2004). Transforming the Curriculum in Law, I, Phillips, D. and Turney, L. eds. Institutional Racism in Higher Education. Stoke on Trent: Trentham Books.

Thomas, L., May, H. et al (2005). From the Margins to the Mainstream. London: UK.

Turney, L., Law, I. \& Phillips, D. (2002) Institutional Racism in Higher Education Toolkit Project: Building the Anti-Racist HEI. [Online]. (last accessed 16/08/2005). (URL www.leeds.ac.uk/cers/toolkit/ toolkit.htm. )

Watson, D (2006). How to Think about Widening particiption in UK Higher Education. [Online]. (last accessed on 20/08/08) (URL www.hefce.ac.uk/pubs/rdreports/2006/rd13_06)

Webb, S. (1997). Alternative Students? Conceptualisations of Difference. In:Williams, J. ed. Negotiating Access to Higher Education. Buckingham: SRHE/Open University Press.

Woodrow, M. (1998). From Elitism to Inclusion. London: CVCP.

Woodrow, M., Yorke, M. et al (2002). Social Class and Participation, London: UK. 